\title{
Is Laparoscopic Cholecystectomy a Safe Procedure for Patients Receiving Anticoagulant Therapy?
}

\author{
Wael Fathi Hasaniah Metwalli Afifi El-Sayed Hilal Al-Sayer \\ Talib Hashim J uma Sabah Al-Hadeedi \\ Department of Surgery, Al-Amiri Hospital, Kuwait
}

\section{Key Words}

Laparoscopic cholecystectomy - Anticoagulant therapy . Atrial fibrillation

\begin{abstract}
Objective: To evaluate the safety of laparoscopic cholecystectomy (LC) in patients on oral anticoagulant therapy. Methods: Four patients were involved in this study on whom the procedure was performed in a conventional manner paying meticulous attention to haemostasis. The oral anticoagulant was resumed the night of the operation, and the patient was discharged and acceptable international normalised ratio was achieved postoperatively. Results: There was no thrombo-embolic or haemorrhagic complication. The mean hospital stay was 5 days. Conclusion: LC can be safely performed in patients on oral anticoagulant therapy.
\end{abstract}

Copyright $\odot 2002$ S. Karger AG, Base

\section{Introduction}

Laparoscopic cholecystectomy (LC) is now widely accepted as the procedure of choice for treating patients with benign gall bladder diseases. It has relatively few contraindications and is considered a safe procedure with low morbidity and mortality. It also has the advantage of reducing hospital stay compared to the open technique; therefore it is a more cost-effective procedure $[1,2]$.

As this procedure, unlike open cholecystectomy, involves the use of small wounds for the ports and hook diathermy for dissection, which might implicate a higher chance of bleeding, the question of safety arises when operating on patients taking oral anticoagulant therapy. Few reports in the literature [3, 4] suggest that proper control of the doses of anticoagulant in patients undergoing LC is not associated with increased morbidity related to anticoagulation. The aim of this study was to evaluate the morbidity of anticoagulants in patients undergoing LC and to revalidate its safety.

\section{Patients and Methods}

Four patients who were on chronic oral anticoagulant therapy underwent laparoscopic cholecystectomy during 1992-1997. (These patients were analysed as shown in table 1). The patients ( 3 females, 1 male) were between 38 and 75 years of age. They were all taking warfarin (coumarin) orally 4-6 mg daily, for periods of 18 months to 4 years. The patients were instructed to stop oral anticoagulants 2 days prior to operation.

On admission to the hospital each of the 4 patients was examined by a physician to evaluate their medical and cardiac status. A coagu-

\begin{tabular}{ll}
\hline KARGER & ( 2002 S. Karger AG, Basel \\
$1011-7571 / 02 / 0112-0105 \$ 18.50 / 0$ \\
$\begin{array}{l}\text { Fax }+41613061234 \\
\begin{array}{l}\text { E-Mail karger@karger.ch } \\
\text { www.karger.com }\end{array}\end{array}$ & $\begin{array}{l}\text { Accessible online at: } \\
\text { www.karger.com/journals/mpp }\end{array}$
\end{tabular}

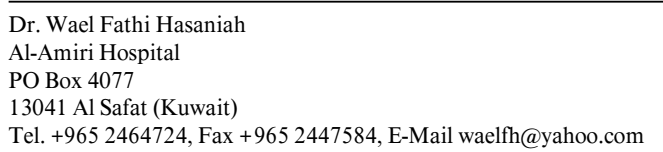


Table 1. Clinical data

\begin{tabular}{|c|c|c|c|c|}
\hline & Patient 1 & Patient 2 & Patient 3 & Patient 4 \\
\hline Operative time & $60 \mathrm{~min}$ & $68 \mathrm{~min}$ & $60 \mathrm{~min}$ & $100 \mathrm{~min}$ \\
\hline Duration of anticoagulation & 18 months & 4 years & 1 year & 2 years \\
\hline Indication for anticoagulation & $\begin{array}{l}\text { aortic valve } \\
\text { replacement }\end{array}$ & $\begin{array}{l}\text { mitral and aortic } \\
\text { valve replacement }\end{array}$ & chronic $\mathrm{AF}$ & $\begin{array}{l}\text { mitral valve } \\
\text { replacement }\end{array}$ \\
\hline Dose of anticoagulant & $5 \mathrm{mg}$ & $4 \mathrm{mg}$ & $6 \mathrm{mg}$ & $6 \mathrm{mg}$ \\
\hline Other medical diseases & $\mathrm{DM}$ & DM, HTN & HTN, IHD & none \\
\hline Cardiac function & $\begin{array}{l}\text { EF } 63 \% \\
\text { mild MR }\end{array}$ & $\mathrm{EF} 68 \%$ & $\begin{array}{l}\text { EF } 66 \% \\
\text { severe MR }\end{array}$ & EF $65 \%$ \\
\hline Indication for LC & $\mathrm{CCC}$ & $\mathrm{CCC}$ & $\mathrm{CCC}$ & $\mathrm{CCC}$ \\
\hline Hospital stay & 4 days & 6 days & 5 days & 4 days \\
\hline
\end{tabular}

$\mathrm{CCC}=$ Chronic calcular cholecystitis; $\mathrm{EF}=$ ejection fraction; $\mathrm{DM}=$ diabetes mellitus; $\mathrm{HTN}=$ hypertension; $\mathrm{AF}=$ atrial fibrillation; $\mathrm{MR}=$ mitral regurge; $\mathrm{IHD}=$ ischaemic heart disease.

lation profile including the international normalised ratio (INR) and grouping with cross-matching 2 units of packed cells was performed.

If the INR was $<1.5$, the patient was put on heparin by intravenous infusion pump at a rate of 1,000-1,500 units per hour; infusion was discontinued $6 \mathrm{~h}$ before the operation as occurred in patient 2; however, if the INR was between 1.5 and 2.0, the operation was performed without any heparin as was the case with patients 1,3 and 4 .

Antibiotics in the form of $80 \mathrm{mg}$ gentamicin and $2 \mathrm{~g}$ ampicillin were given to all patients with the induction of anaesthesia as prophylaxis against subacute bacterial endocarditis and repeated $4 \mathrm{~h}$ after surgery $[5,6]$.

After carbon dioxide insufflation through umbilical port entry, laparoscopic cholecystectomy was performed through four ports [7] Briefly, hook diathermy was used to dissect Calot's triangle to identify the cystic artery and cystic duct. The gall bladder was dissected from its bed using the hook to control any bleeding. Meticulous haemostasis was maintained.

The coagulation profile and the INR were checked immediately after operation. If the INR was still in the range of 1.5-2.0, oral anticoagulant therapy was resumed. On the other hand, if the INR was $<1.5$ then heparin was started $6 \mathrm{~h}$ after operation by intravenous infusion pump together with the oral anticoagulant until the recommended INR was achieved.

\section{Results}

The average blood loss during the surgical procedure (LC) was approximately $50 \mathrm{ml}$ and the operative time ranged from 60 to 100 min with an average of 72 min per procedure. A perioperative cholangiogram was not performed in these patients, and as there was no indication, drains were not used. None of the patients required blood transfusion and none of them developed any thromboembolic, haemorrhagic or cardiac complications. The hospital stay ranged from 4 to 6 days. All 4 patients with an INR between 2.0 and 2.5 were discharged on their usual dose of oral anticoagulant, and each was referred to the treating cardiologist for follow-up.

\section{Discussion}

Laparoscopic cholecystectomy has a risk of deep vein thrombosis reported in the literature between 1 and 1.5\% [8-10]. Patients with prosthetic aortic or mitral valves, and patients with atrial fibrillation who are on long-term anticoagulants are at risk of thrombo-embolic and bleeding complications during and after surgery if their INR is not controlled pre- and perioperatively [11, 12].

Previously, it was thought that LC was hazardous in patients receiving oral anticoagulants. However, with wider experience and the improvement in pre- and postoperative care, surgery in patients taking anticoagulants is not contraindicated provided that the INR is kept between 1.5 and 2.0 at the time of operation [3]. Meticulous haemostasis using hook diathermy during the operation is mandatory to avoid complications.

\section{Conclusion}

Laparoscopic cholecystectomy is a safe procedure in patients taking oral anticoagulants provided that there is proper control to keep the INR in the range 1.5-2.0 during pre-, peri- and postoperative periods. 


\section{References}

1 Schirmer BD, Edge SB: Laparoscopic cholecystectomy: Treatment of choice for symptomatic cholelithiasis. Ann Surg 1991;213:665-667.

2 Peters JH, Ellison EC, Innes JT, Liss JL, Nichols KE, Lomano JM, Roby SR, Front ME, Carey C: Safety and efficacy of laparoscopic cholecystectomy: A prospective analysis of 100 initial patients. Ann Surg 1991;213:3-12.

3 Fitzgerald SD, Bailey PV, Liebscher GJ, Andrus CH: Laparoscopic cholecystectomy in anticoagulated patients. Surg Endosc 1991;5: 166-169.

4 Yoshida T, Kitano S, Matsumoto T, Bandoh T, Baatar D, Ninomiya K, Hadama T: Laparoscopic cholecystectomy in patients undergoing anticoagulant therapy. Surg Today 1998;28. 308-312.
5 Kosuga K, Aoyagi S, Shima H, Yanagi I, Oryoji A, Oishi K, Koga M: Surgery for patients on anticoagulants following prosthetic valve replacement. Nippon Geka Gakkai Zasshi 1987; 88:779-784.

6 Durak DT: Infective Endocarditis; in Cecil RL (ed): Cecil Textbook of Medicine. Philadelphia, Saunders, 1992, pp 1638-1647.

7 Voyles CR, Meena AL, Petro AB, Haick AJ, Koury AM: Electrocautery is superior to laser for laparoscopic cholecystectomy. Am J Surg 1990;160:457.

8 Bounameaux H, Didier D, Polat O, Desmarais S, Moerlosse P, Huban O: Anti thrombotic prophylaxis in patients undergoing laparoscopic cholecystectomy. Thromb Res 1997;86:271273.
9 Caprini JA, Arcelus JL, Laubach M, Size G, Hoffman KN, Coats RW II, Blattner S: Postoperative hypercoagulability and deep vein thrombosis after laparoscopic cholecystectomy. Surg Endosc 1995;9:304-309.

10 Jorgensen J, Hanel K, Lalak NJ, Hunt DR, North L, Morris DL: Thromboembolic complications of laparoscopic cholecystectomy. BMJ 1993;306:518-519.

11 Bodnar AG, Hutter AM Jr: Anticoagulation in valvular heart disease preoperatively and postoperatively. Cardiovasc Clin 1984;14:247264.

12 Travis S, Wray R, Harrison K: Perioperative anticoagulant control. Br J Surg 1989;76:11071108. 